\title{
Association of SOX2 and Nestin DNA amplification and protein expression with clinical features and overall survival in non-small cell lung cancer: A systematic review and meta-analysis
}

\author{
Qingbao $\mathrm{Li}^{1}$, Fang Liu ${ }^{2}$, Yuan Zhang ${ }^{3}$, Lei Fu ${ }^{4}$, Cong Wang ${ }^{5}$, Xuan Chen ${ }^{5}$, Shanghui \\ Guan $^{5}$, Xiangjiao Meng ${ }^{4}$ \\ ${ }^{1}$ Department of Cardiac Surgery, Shandong Provincial Hospital Affiliated to Shandong University, Jinan, 250021, China \\ ${ }^{2}$ Department of Image, Shandong Medical College, Jinan, 250002, China \\ ${ }^{3}$ Department of Laboratory Medicine, Shandong Medical College, Jinan, 250002, China \\ ${ }^{4}$ Department of Radiation Oncology, Shandong Cancer Hospital and Institute, Jinan, 250117, China \\ ${ }^{5}$ Department of Radiation Oncology, Qilu Hospital of Shandong University, Jinan, 250012, China
}

Correspondence to: Xiangjiao Meng, email: sdxjmeng@163.com

Keywords: meta-analysis, SOX2, Nestin, clinical outcome, non-small cell lung cancer

Received: January 04, $2016 \quad$ Accepted: April 16, $2016 \quad$ Published: May 02, 2016

\section{ABSTRACT}

Up to now, the prognosis of non-small cell lung cancer (NSCLC) is poor. With progress of cancer biology, a number of genes have been investigated for predicting prognosis of NSCLC, such as cancer stem cell markers SRY (sex determining region Y)-box 2 (SOX2) and Nestin. Recently, a series of studies have been performed to examine the associations of SOX2 and Nestin with clinical parameters and prognosis in NSCLC, however, the results were not consistent. In the present study, we conducted a systematic review and meta-analysis to summarize the associations. Four English databases (PubMed, ISI web of science, Embase, and Ovid) were used to search the relevant studies with the last date of November 10, 2015. The pooling analyses were stratified by DNA amplification and protein expression. The pooling ORs or HRs were used to assess the strength of the associations. Finally, we included 19 articles for SOX2 and six articles for Nestin according to the inclusion and exclusion criteria. The pooling analyses revealed that there were significant associations between SOX2 DNA amplification and clinical features of NSCLC, gender, smoking status, squamous cell cancer (SCC) histology, and differentiations. And significant associations were also identified between SOX2 protein expression and clinical parameters, smoking status and SCC histology. For Nestin, its protein expression was correlated with lymph node metastasis and stage. Simultaneously, we found that high/positive SOX2 alterations, either DNA amplification or protein expression, were favorable for overall survival (OS) in NSCLC. On the contrary, high/ positive Nestin protein expression was poor for $0 S$.

\section{INTRODUCTION}

Lung cancer is the leading cause of cancer death worldwide and its 5-year relative survival rate is low [1]. Traditionally, it is classified into two major subtypes, small cell lung cancer (SCLC) and non-small cell lung cancer (NSCLC). The latter can be subdivided into adenocarcinoma (ADC), squamous cell carcinoma (SCC), and large cell carcinoma (LCC) [2].
In recent years, some activated oncogenes such as Epidermal Growth Factor Receptor (EGFR) mutations and Anaplastic Lymphoma Kinase (ALK) rearrangements have been found and used as novel therapeutic targets [3-5]. All these progresses encourage the researchers to identify new biomarkers or therapeutic targets. Of which, the cancer stem cell markers such as SRY (sex determining region Y)-box 2 (SOX2) and Nestin have gotten researchers interested. 
SOX2 locates on chromosome 3q26.33 and encodes a transcription factor of 317 amino acids [6, 7]. It has been reported to be involved in pluripotency regulation in embryonic stem cells and the morphogenesis and homoeostasis of tracheobronchial epithelia [8]. Recently, SOX2 aberrant DNA amplification and protein expression have been found in various types of tumors. Functional experiments suggest that $S O X 2$ is responsible for cellular proliferation, tumor invasion and migration, self-renewal, maintenance in cancer stem cell populations, and lung tumorigenesis [6, 9-12]. It also has been reported that DNA amplification and protein expression of $S O X 2$ are associated with clinicopathological features and prognosis in lung cancers, however, the results are not always consistent [13-16]. Although a meta-analysis in the year of 2013 has been performed to summarize the associations, the included studies were relatively rare and the authors do not distinguish SOX2 DNA amplification, mRNA expression, and protein expression [17].

Nestin is a member of the intermediate filament (IF) family and serves as a potential proliferative and muti-potency marker in progenitor and stem cells [18, 19]. Nestin has been also found to have an anti-apoptotic function through inhibiting caspase activation [20]. Recent observations have revealed a link between Nestin aberrant expression and malignant characteristics and poor prognosis in different cancers [21-25].

In the present study, we performed a systematic review and meta-analysis to investigate the associations of DNA amplification and protein expression of $S O X 2$ and Nestin with clinicopathological features and overall survival in NSCLC.

\section{RESULTS}

\section{Study characteristics}

The literature selection process was shown in Figure 1. Four English databases were used and a total of 1442 documents were initially identified. After excluding those duplicated records, animal experiments or cellular studies, non-NSCLC related studies, and non-original articles, 36 full texts were left for further evaluation. Subsequently, six articles were excluded due to insufficient data [26-31], and one was excluded because it contained other type of lung cancer besides NSCLC [32]. Here, we only focused on DNA amplification and protein expression. Then another four studies were excluded due to only reporting the SOX2 or Nestin mRNA related data [33-36]. Finally, 25 papers were included in the present study [13-16, 21, 37-56]. Of which, 19 articles reported SOX2 DNA amplification and/or protein expression [13-16, 37-51], six articles reported Nestin protein expression, and none reported Nestin DNA amplification [21, 52-56]. In addition, Velcheti et al. [46] and Iijima et al. [50] reported two independent cohorts, respectively, and each cohort was considered as independent study in the meta-analysis. The included studies were published from 2010 to 2015 and the sample size ranged from 33 to 758 . In the original studies, the DNA amplification was determined by PCR or FISH ( $n=3$ and 6 ) and the protein expression was determined by IHC or IF $(n=19$ and 2). The detailed characteristics of the included studies were shown in Table 1.

\section{Meta-analysis results}

\section{SOX2}

Significant associations were identified between high/positive SOX2 DNA amplification and clinicopathological features, gender $(\mathrm{OR}=1.969$, 95\% $\mathrm{CI}=1.050-3.693, P=0.035)$, smoking status $(\mathrm{OR}=2.830$, $95 \% \mathrm{CI}=1.269-6.310, P=0.011)$, histology $(\mathrm{OR}=8.136$, 95\% CI $=2.136-30.997, P=0.000)$, differentiation $(\mathrm{OR}=1.644,95 \% \mathrm{CI}=1.119-2.415, P=0.011)$, and OS $(\mathrm{HR}=0.732,95 \% \mathrm{CI}=0.593-0.904, P=0.004)$ (Figure 2 and Table 2). For $S O X 2$ protein expression, $i$ ts associations with smoking status $(\mathrm{OR}=2.245,95 \%$ $\mathrm{CI}=1.008-\quad 5.001, P=0.048)$, histology $(\mathrm{OR}=5.437$, $95 \% \mathrm{CI}=2.344-12.610, P=0.000)$, and $\mathrm{OS}(\mathrm{HR}=0.579$, $95 \% \mathrm{CI}=0.359-0.934, P=0.025$ ) were found (Figure 2 and Table 2).

\section{Nestin}

There was no study reporting Nestin DNA amplification in NSCLC and then only Nestin protein expression was analyzed. The pooling analyses revealed significant associations of Nestin protein expression with lymph node matastasis $(\mathrm{OR}=2.732$, 95\% $\mathrm{CI}=1.393-5.376, P=0.004)$, stage $(\mathrm{OR}=1.996,95 \%$ $\mathrm{CI}=1.157-3.445, P=0.013)$, and $\mathrm{OS}(\mathrm{HR}=2.166,95 \%$ $\mathrm{CI}=1.437-3.263, P=0.000$ ) (Figure 3 and Table 2).

\section{Heterogeneity and sensitivity analysis}

\section{SOX2}

The heterogeneity and sensitivity were analyzed by subgroup analysis according to ethnicity, histology, and sample size or excluding single individual study. The results indicated that the heterogeneity existed in evaluating the associations of SOX2 DNA amplification with gender $\left(I^{2}=\right.$ $55.6 \%)$, smoking status $\left(I^{2}=62.2 \%\right)$, histology $\left(I^{2}=89.7 \%\right)$, and differentiation (poor vs. well + moderate, $I^{2}=68.2 \%$ ) (Table 2). For gender, heterogeneity decreased to $31.4 \%$ after excluding Wilbertz et al's study and the pooling OR was not influenced. For smoking status, after grouping by China and non-China studies, heterogeneity of both subgroups decreased to $0 \%$ and the associations were still significant. For histology, the heterogeneity could not be removed by subgroup analyses or excluding single individual study. For differentiation, the heterogeneity deceased $\left(I^{2}=19.3 \%\right)$ by excluding the study of Zhang et al. 2015 and the pooling 
OR was not influenced. Meanwhile, there were significant heterogeneity in assessment of the associations of SOX2 protein expression with gender $\left(I^{2}=55.1 \%\right)$, age $\left(I^{2}=90.3 \%\right)$, smoking status $\left(I^{2}=58.9 \%\right)$, histology $\left(I^{2}=68.7 \%\right)$, and OS $\left(I^{2}=84.9 \%\right)$. The heterogeneity deceased significantly when deleting single individual studies of Chou et al. 2013 (gender, $P^{2}=38.7 \%$ ), Chen et al. 2012 (age, $P^{2}=15.0 \%$ ), Zheng et al. 2015 (smoking status, $I^{2}=0 \%$ ), and Li et al. 2012 (histology, $P^{2}=34.5 \%$ ), respectively. And the pooled ORs were not influenced, suggesting the results were stable. For OS, the heterogeneity still existed when excluding single individual study one by one. In subgroup analysis stratified by histology (SCC, $n=4$; $\mathrm{ADC}, n=1$; and SCC/ADC, $n=4$ ), heterogeneity was $29.7 \%$ in SCC, and $90.3 \%$ in SCC/ ADC. And the association was significant in SCC but not SCC/ADC.

\section{Nestin}

As shown in Table 2, there was heterogeneity in assessment of the associations of Nestin protein expression with smoking status $\left(I^{2}=60.7 \%\right)$, histology $\left(I^{2}=92.0 \%\right)$, differentiation $\left(I^{2}=94.6 \%\right)$, and OS $\left(I^{2}=68.4 \%\right)$. When the studies of Chen et al. 2010, Ryuge et al. 2011, and Janikova et al. 2012 were excluded, respectively, the heterogeneity significantly decreased (smoking status, $I^{2}=0 \%$; differentiation, $I^{2}=0 \%$; and $\left.\mathrm{OS}, I^{2}=48.2 \%\right)$ and the pooling ORs were not influenced except differentiation. As for histology, subgroup analysis suggested that the heterogeneity among the studies performed in China was decreased $\left(I^{2}=0 \%\right)$ and a significant association was presented. But the heterogeneity still existed in Japan group $\left(I^{2}=95.5 \%\right)$.
Articles identified after a comprehensive search $(n=1442$;

PubMed=249; Embase=283; Web of Science $=390$; Ovid $=520$ )
Study excluded: 930-Duplicated papers;
Study excluded:

347-Animal experiments or cell cellular studies;

105-Non-NSCLC related article

25-Non original articles (review, letter, and meeting abstracts)

\section{Screening by reading the full texts of the retrieved articles $(n=36)$}

Study excluded: 6-No sufficient data; 4-Sox2 mRNA expression; 1-Contain Non-NSCLC cancers
Eligible publications included into our study ( $n=25$ : Sox2=19; Nestin=6)

Figure 1: Flow chart of study selection. 
Table 1: Characteristics of the included studies

\begin{tabular}{|c|c|c|c|c|c|c|c|}
\hline Reference & Country & $\begin{array}{l}\text { Patient } \\
\text { No. }\end{array}$ & Age (year) & Method & Cut-off value & $\begin{array}{c}\text { Protein/ } \\
\text { Amplification }\end{array}$ & $\begin{array}{l}\text { Positive/ } \\
\text { Negative }\end{array}$ \\
\hline \multicolumn{8}{|l|}{ SOX2 } \\
\hline Yuan et al. 2010 & USA & 57 & & IHC & $\begin{array}{l}\text { SCC (high > 270, } \\
\text { low < 140); ADC } \\
(\text { high > 193, low } \\
<10)\end{array}$ & Protein & $37 / 19$ \\
\hline Yuan et al. 2010 & USA & 57 & & qPCR & 4 copy & Amplification & $8 / 49$ \\
\hline Lu et al. 2010 & USA & 40 & & $\mathrm{IHC}$ & $5 \%$ & Protein & $19 / 21$ \\
\hline Sholl et al. 2010 & USA & 104 & $68(36-91)$ & $\mathrm{IHC}$ & $5 \%$ & Protein & $52 / 52$ \\
\hline Sholl et al. 2010 & USA & 66 & & $\mathrm{IHC}$ & $5 \%$ & Protein & $41 / 25$ \\
\hline Wilbertz et al. 2011 & \begin{tabular}{|l} 
Switzerland/ \\
USA \\
\end{tabular} & 758 & & FISH & $30 \%$ & Amplification & $224 / 534$ \\
\hline Cai et al. 2011 & China & 115 & $58(27-77)$ & PCR & Ratio $>M+2 S D$ & Amplification & $30 / 85$ \\
\hline Cai et al. 2011 & China & 150 & $58(27-77)$ & $\mathrm{IHC}$ & $5 \%$ & Protein & $79 / 71$ \\
\hline Koji et al. 2011 & Japan & 309 & & $\mathrm{IHC}$ & $5 \%$ & Protein & \\
\hline Sasaki et al. 2012 & Japan & 127 & $66.0 \pm 10.2$ & PCR & 4 copy & Amplification & $42 / 85$ \\
\hline Brcic et al. 2012 & American & 147 & & $\mathrm{IHC}$ & $5 \%$ & Protein & $14 / 52$ \\
\hline Brcic et al. 2012 & American & 147 & & FISH & $\mathrm{CN} /$ chrom $>2$ & Amplification & $18 / 52$ \\
\hline Li et al. 2012 & China & 44 & & $\mathrm{IHC}$ & $10 \%$ & Protein & $31 / 13$ \\
\hline Chen et al. 2012 & China & 381 & & $\mathrm{IHC}$ & $10 \%$ & Protein & $374 / 7$ \\
\hline Velcheti et al. 2013 & Greek & 340 & $62.32 \pm 9.04$ & IF & Score $>193$ & Protein & \multirow{2}{*}{$418 / 229$} \\
\hline Velcheti et al. 2013 & USA & 307 & $65.17 \pm 9.92$ & IF & Score $>193$ & Protein & \\
\hline Chou et al. 2013 & China & 175 & & $\mathrm{IHC}$ & No stain in nuclear & Protein & $51 / 124$ \\
\hline Yusuke et al. 2015 & Japan & 282 & $67(33-86)$ & FISH & Mean value & Amplification & $34 / 244$ \\
\hline Toschi et al. 2015 & Italy & 447 & & FISH & $\begin{array}{l}4 \text { copy or presence } \\
\text { of gene cluster }\end{array}$ & Amplification & $105 / 340$ \\
\hline Yoon et al. 2015 & Korea & 33 & $66(48-73)$ & $\mathrm{IHC}$ & Internal control & Protein & $22 / 11$ \\
\hline Yoon et al. 2015 & Korea & 33 & $66(48-73)$ & FISH & 10 green signal & Amplification & $26 / 7$ \\
\hline Iijima et al. 2015 & China cohort & 57 & & $\mathrm{IHC}$ & H-score $>0$ & Protein & $40 / 17$ \\
\hline Iijima et al. 2015 & Japan cohort & 66 & & $\mathrm{IHC}$ & H-score $>0$ & Protein & $45 / 21$ \\
\hline Zheng et al. 2015 & China & 162 & $61.6(40-88)$ & $\mathrm{IHC}$ & 100 score & Protein & $85 / 65$ \\
\hline Zheng et al. 2015 & China & 162 & $61.6(40-88)$ & FISH & 4 gene copy & Amplification & $50 / 61$ \\
\hline \multicolumn{8}{|l|}{ Nestin } \\
\hline Chen et al. 2010 & China & 52 & $58.2 \pm 10.0$ & $\mathrm{IHC}$ & \begin{tabular}{|l}
$8.4($ median \\
histoscore of \\
Nestin $)$ \\
\end{tabular} & Protein & $25 / 27$ \\
\hline Janikova et al. 2010 & Czech & 121 & & $\mathrm{IHC}$ & $10 \%$ & Protein & $74 / 38$ \\
\hline Ryuge et al. 2011 & Japan & 173 & $64(34-85)$ & $\mathrm{IHC}$ & $5 \%$ & Protein & $27 / 144$ \\
\hline Skarda et al. 2012 & \begin{tabular}{|l|} 
Czech \& \\
Israel \\
\end{tabular} & 115 & 60.3 & IHC & H-score $>0$ & Protein & $40 / 74$ \\
\hline Chen et al. 2014 & China & 71 & $57.6 \pm 9.8$ & IHC & $\begin{array}{l}8.4(\text { median } \\
\text { histoscore of } \\
\text { Nestin) }\end{array}$ & Protein & $35 / 36$ \\
\hline Sterlacci et al. 2014 & Austria & 215 & & IHC & $\begin{array}{l}\text { Median \% positive } \\
\text { staining cell }\end{array}$ & Protein & $57 / 269$ \\
\hline
\end{tabular}




\section{A SOX2 Amplification}

Study Gender (male vs. female)

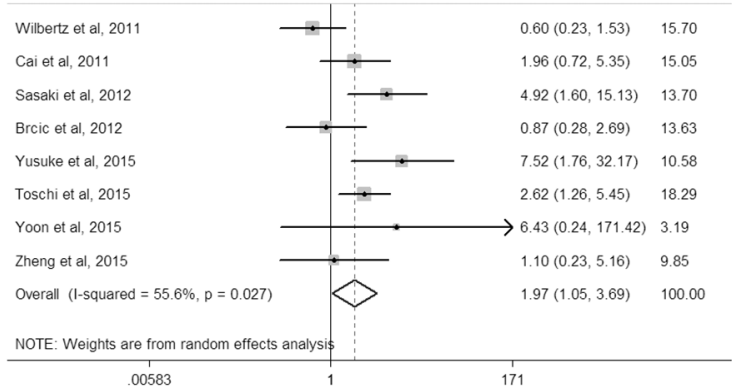

Study Histology (SCC vs. ADC)

Yenn

Yuan et al, 20

Wilbertz et al, 2011

Wilbertz et al, 201

Yusuke et al, 2015

Toschi et al, 2015

Overall (1-squared $=89.7 \%, p=0.000)$

NOTE: Weights are from random effects analysis 0018

B SOX2 Protein expression

Study Smoking status (yes vs. no)

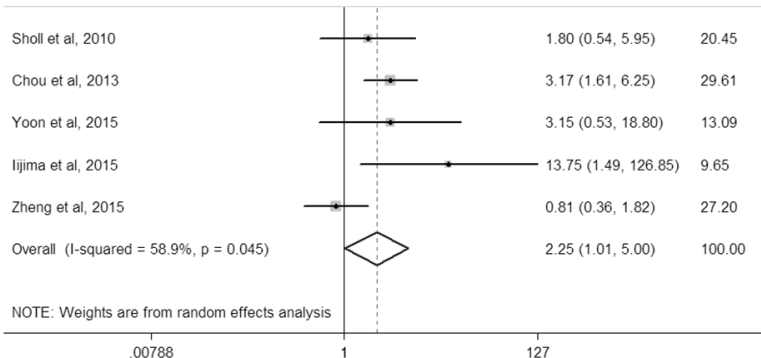

C Overall survival

study SOX2 Amplification

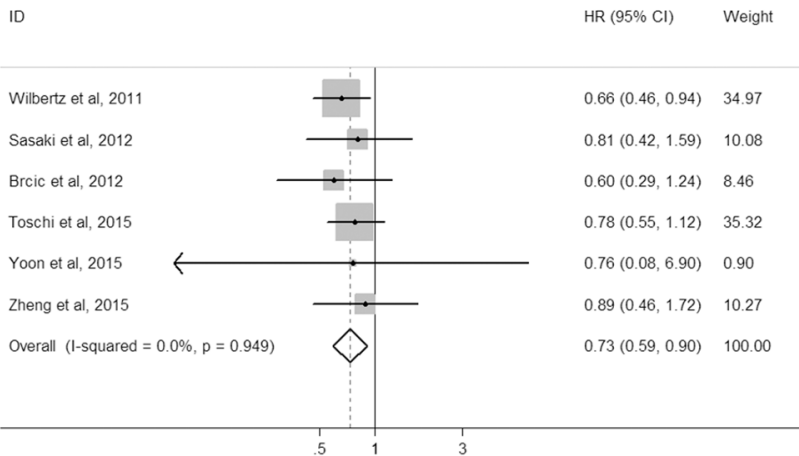

Study Smoking status (yes vs. no)

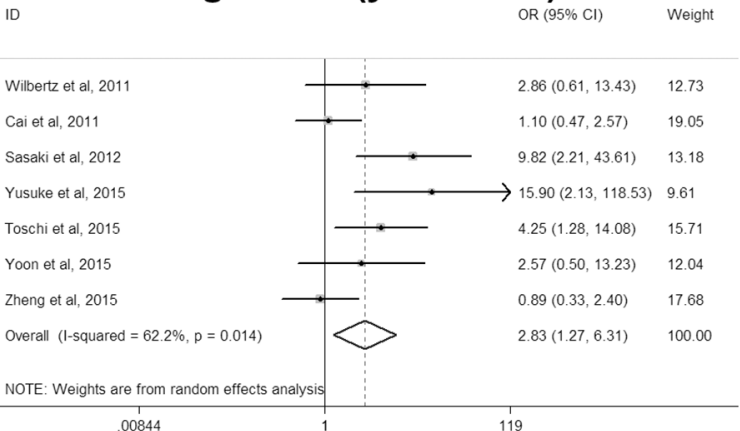

Study Differentiation (moderate+poor vs. well)
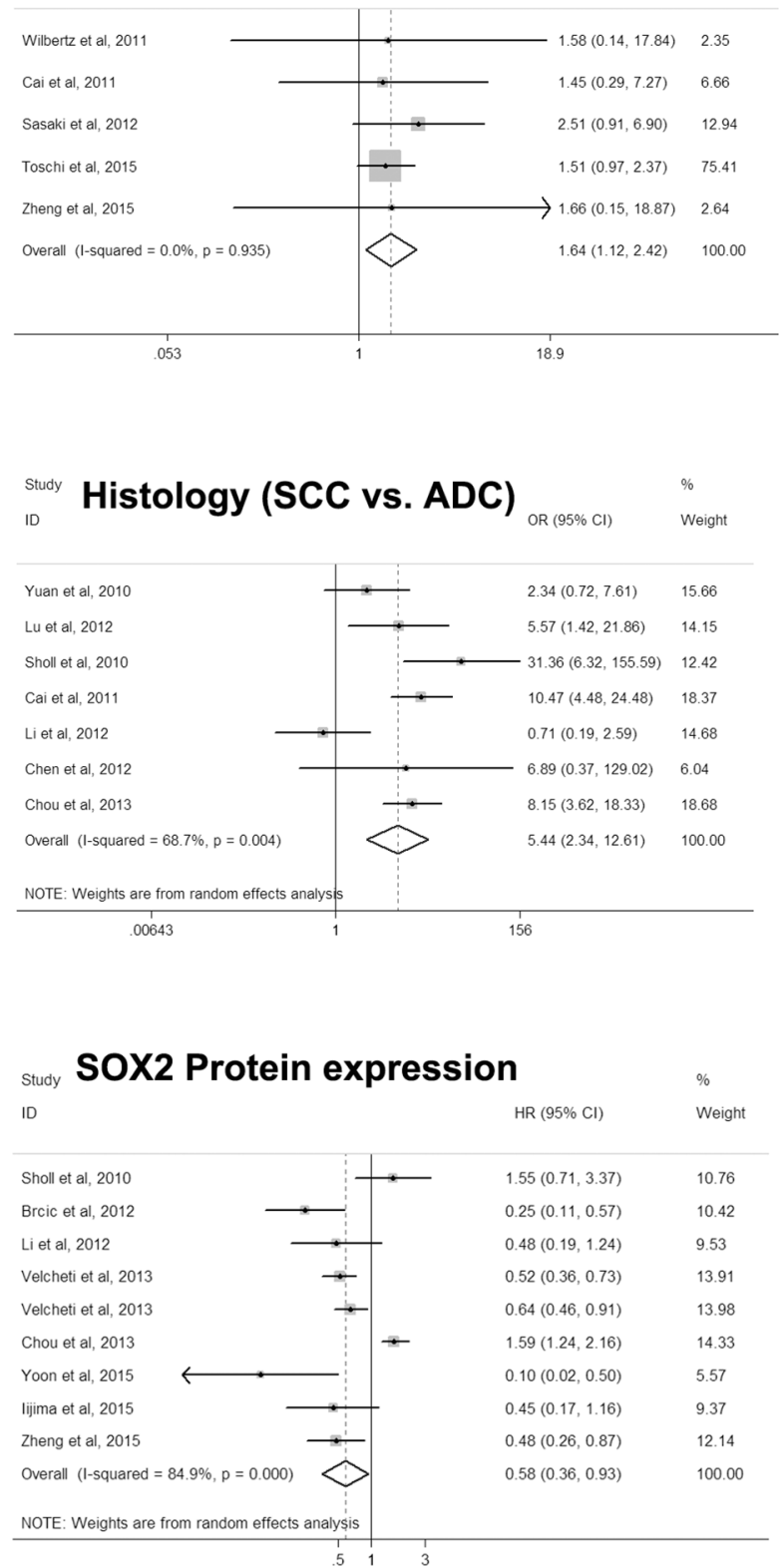

Figure 2: Forest plot for associations of $S O X 2$ with clinicopathological features and overall survival in NSCLC. 
Table 2: Meta-analysis results

\begin{tabular}{|c|c|c|c|c|c|c|c|c|c|}
\hline Clinical parameters & $N$ & OR/HR & $\begin{array}{l}\text { OR/ } \\
\text { HR95\%CI }\end{array}$ & $P_{O R}$ & Model & $I^{2}$ & $P_{\text {hetero }}$ & $\boldsymbol{P}_{\text {Eegg }}$ & $\boldsymbol{P}_{\text {Egger }}$ \\
\hline \multicolumn{10}{|l|}{ SOX2 Amplification } \\
\hline Gender(male vs. female) & 8 & 1.969 & $1.050-3.693$ & 0.035 & $\mathrm{R}$ & 55.6 & 0.027 & 0.711 & 0.652 \\
\hline Age $(\leq 60$ vs. $>60$ or $\leq 65$ vs. $>65)$ & 3 & 0.857 & $0.507-1.448$ & 0.563 & $\mathrm{~F}$ & 0.6 & 0.365 & 1.000 & 0.367 \\
\hline Smoking status (yes vs. no) & 7 & 2.830 & $1.269-6.310$ & 0.011 & $\mathrm{R}$ & 62.2 & 0.014 & 0.368 & 0.052 \\
\hline Histology (SCC vs. ADC) & 6 & 16.530 & $5.134-53.221$ & 0.000 & $\mathrm{R}$ & 89.7 & 0.000 & 0.707 & 0.885 \\
\hline Differentiation (moderate+ + poor vs. well) & 5 & 1.644 & 1.119-2.415 & 0.011 & $\mathrm{~F}$ & 0.0 & 0.935 & 0.462 & 0.629 \\
\hline Differentiation (poor vs. well+moderate) & 3 & 0.807 & $0.317-2.054$ & 0.654 & $\mathrm{R}$ & 68.2 & 0.041 & 1.000 & 0.796 \\
\hline Lymph node metastasis $\left(\mathrm{N}_{0}\right.$ vs. $\left.\mathrm{N}_{1-3}\right)$ & 5 & 0.943 & $0.678-1.312$ & 0.728 & $\mathrm{~F}$ & 0.0 & 0.650 & 0.806 & 0.688 \\
\hline Lymph nodemetastasis $\left(\mathrm{N}_{0-1}\right.$ vs. $\left.\mathrm{N}_{2-3}\right)$ & 3 & 0.903 & $0.468-1.743$ & 0.761 & $\mathrm{~F}$ & 0.0 & 0.418 & 0.308 & 0.168 \\
\hline Stage (I vs. II-IV) & 5 & 1.222 & $0.860-1.737$ & 0.263 & $\mathrm{~F}$ & 0.0 & 0.855 & 0.221 & 0.363 \\
\hline Stage (I-II vs. III-IV) & 4 & 1.226 & $0.877-1.714$ & 0.232 & $\mathrm{~F}$ & 0.0 & 0.849 & 0.734 & 0.690 \\
\hline OS & 6 & 0.732 & $0.593-0.904$ & 0.004 & $\mathrm{~F}$ & 0.0 & 0.949 & 0.707 & 0.794 \\
\hline \multicolumn{10}{|l|}{ SOX2 Protein expression } \\
\hline Gender(male vs. female) & 9 & 1.345 & $0.726-2.493$ & 0.558 & $\mathrm{R}$ & 55.1 & 0.023 & 0.917 & 0.738 \\
\hline Age $(\leq 60$ vs. $>60$ or $\leq 65$ vs. $>65)$ & 6 & 0.439 & $0.104-1.857$ & 0.263 & $\mathrm{R}$ & 90.3 & 0.000 & 0.368 & 0.199 \\
\hline Smoking status (yes vs. no) & 5 & 2.245 & $1.008-5.001$ & 0.048 & $\mathrm{R}$ & 58.9 & 0.045 & 0.806 & 0.537 \\
\hline Histology (SCC vs. ADC) & 7 & 5.437 & $2.344-12.610$ & 0.000 & $\mathrm{R}$ & 68.7 & 0.004 & 1.000 & 0.749 \\
\hline Differentiation (moderate+poor vs. well) & 6 & 1.082 & $0.695-1.685$ & 0.726 & $\mathrm{~F}$ & 0.0 & 0.694 & 1.000 & 0.471 \\
\hline Differentiation (poor vs. well+moderate) & 9 & 0.723 & $0.517-1.011$ & 0.058 & F & 14.2 & 0.316 & 1.000 & 0.496 \\
\hline Lymph node metastasis $\left(\mathrm{N}_{0}\right.$ vs. $\left.\mathrm{N}_{1-3}\right)$ & 3 & 1.078 & $0.649-1.789$ & 0.772 & $\mathrm{~F}$ & 0.0 & 0.693 & 1.000 & 0.952 \\
\hline Lymph nodemetastasis ( $\mathrm{N}_{0-1}$ vs. $\left.\mathrm{N}_{2-3}\right)$ & 1 & & & & & & & & \\
\hline Stage (I vs. II-IV) & 4 & 1.2 & $0.807-2.057$ & 0.289 & $\mathrm{~F}$ & 18.4 & 0.298 & 0.734 & 0.959 \\
\hline Stage (I-II vs. III-IV) & 3 & 0.818 & $0.327-2.044$ & 0.667 & $\mathrm{~F}$ & 5.3 & 0.348 & 1.000 & 0.648 \\
\hline $\mathrm{OS}$ & 9 & 0.579 & $0.359-0.934$ & 0.025 & $\mathrm{R}$ & 84.9 & 0.000 & 0.466 & 0.109 \\
\hline \multicolumn{10}{|l|}{ Nestin Protein expression } \\
\hline Gender (male vs. female) & 4 & 0.932 & $0.569-1.527$ & 0.780 & $\mathrm{~F}$ & 11.7 & 0.334 & 0.734 & 0.478 \\
\hline Age $(\leq 60$ vs. $>60$ or $\leq 65$ vs. $>65)$ & 3 & 1.111 & $0.650-1.897$ & 0.701 & $\mathrm{~F}$ & 5.1 & 0.349 & 0.294 & 0.174 \\
\hline Smoking status (yes vs. no) & 3 & 1.237 & $0.486-3.151$ & 0.655 & $\mathrm{R}$ & 60.7 & 0.078 & 1.000 & 0.145 \\
\hline Histology (SCC vs. ADC) & 4 & 2.378 & $0.420-13.462$ & 0.327 & $\mathrm{R}$ & 92.0 & 0.000 & 0.734 & 0.542 \\
\hline Differentiation (well+moderate vs. poor) & 3 & 2.671 & $0.170-41.861$ & 0.484 & $\mathrm{R}$ & 94.6 & 0.000 & 1.000 & 0.335 \\
\hline Lymph node metastasis $\left(\mathrm{N}_{1-3}\right.$ vs. $\left.\mathrm{N}_{0}\right)$ & 2 & 2.732 & $1.393-5.376$ & 0.004 & $\mathrm{~F}$ & 0.0 & 0.694 & & \\
\hline Stage (II-IV vs. I) & 3 & 1.996 & $1.157-3.445$ & 0.013 & $\mathrm{~F}$ & 0.0 & 0.981 & 1.000 & 0.534 \\
\hline OS & 5 & 2.166 & $1.437-3.263$ & 0.000 & $\mathrm{R}$ & 68.4 & 0.013 & 0.806 & 0.534 \\
\hline
\end{tabular}

\section{Publication bias}

Furthermore, publication bias was also assessed by Begg's test and Egger's test. Symmetrical Begg's funnel plots and Egger's test results revealed no publication bias in all comparisons (Figure 4 and Table 2).

\section{DISCUSSION}

A number of studies have been performed to explore the associations of cancer cell stem cell markers, such as SOX2 and Nestin, with clinical parameters and prognosis in various types of cancers including NSCLC. However, the results in the studies were not consistent.

Up to now, there were two meta-analyses tying to investigate the associations of SOX2 with clinicopathological features and/or overall survival in NSCLC [17, 57]. Chen et al. [17] only searched relevant studies in PubMed, up to May 2013 and included eight studies. Shao et al. [57] pooled seven studies published from 2010 to 2013. Neither of the studies distinguished $S O X 2$ DNA amplification, mRNA expression, and protein expression. In the present study, we analyzed $S O X 2$ DNA amplification and protein expression, respectively, 
unlike with the above reports. We searched in more English database and included more articles than the previous meta-analysis (19 vs. 8 and 7 ) although we did not combined the mRNA related studies. Pooling analyses suggested that both of the DNA amplification and the protein expression of $S O X 2$ were associated with smoking status, histology, and OS. In addition, SOX2 DNA amplification was also associated with gender and differentiation. The discrepancy between DNA amplification and protein expression might be caused by the heterogeneity among studies and the inconsistency between amplification and protein expression. More studies examining amplification and protein expression of SOX2 at the same time should be performed to confirm the conclusions. For Nestin, there was only one metaanalysis examining the associations of Nestin protein expression with TNM in regardless of cancer types. And the authors found that Nestin was positively associated
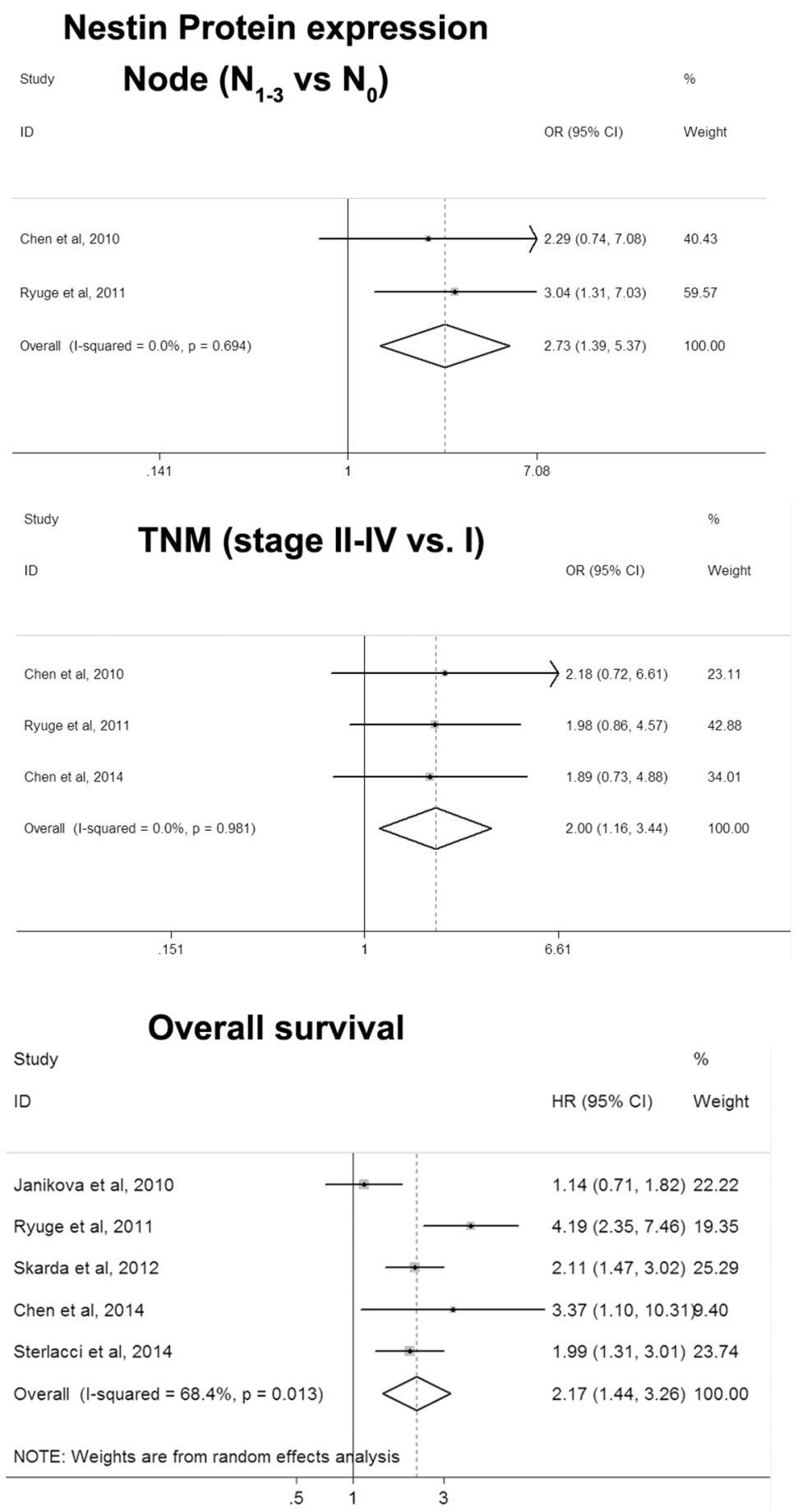

Figure 3: Forest plot for associations of Nestin with clinicopathological features and overall survival in NSCLC. 
with cancer stage and lymph node [58]. In the present meta-analysis, we summarized the associations of Nestin with clinicopathological features and OS in a single type of cancer, NSCLC. The pooling analyses suggested that high/positive Nestin was an indicator of poor prognosis in NSCLC, not as well as $S O X 2$, which was a favorable factor for OS in NSCLC. This might bring us confusion when understanding the role of the two genes in molecular pathogenesis of NSCLC. Because both of them were cancer stem cell markers and mechanisms studies suggested that they all had proliferative and anti-apoptotic effects in vitro and animal model. Combined the results of the previous reports and the present meta-analysis, we proposed a mechanism model that $S O X 2$ was an oncogene and promoted tumorigenesis. Meanwhile, the tumors with SOX2 up-regulation might exhibit a clearer squamous cell differentiation and were associated with better prognosis.
Although we pooled all the potential studies according to the inclusion and exclusion criteria, some limitations existed. Firstly, the number and sample size of Nestin related studies were small. Secondly, the studies of the subgroup of ADC for $S O X 2$ were rare. As the original studies suggested that $S O X 2$ was more frequently upregulated in SCC than ADC, the predictive role of SOX2 in SCC and ADC might be not consistent. Then the impact of $S O X 2$ on prognosis in SCC and ADC should be compared in more studies with larger sample size.

In summary, we got a comprehensive result from the current meta-analysis that $S O X 2$ DNA amplification and protein expression were associated with smoking status and histology, and were favorable for prognosis in NSCLC. And Nestin was associated with cancer stage, lymph node, and poor outcome.

\section{A sox2}
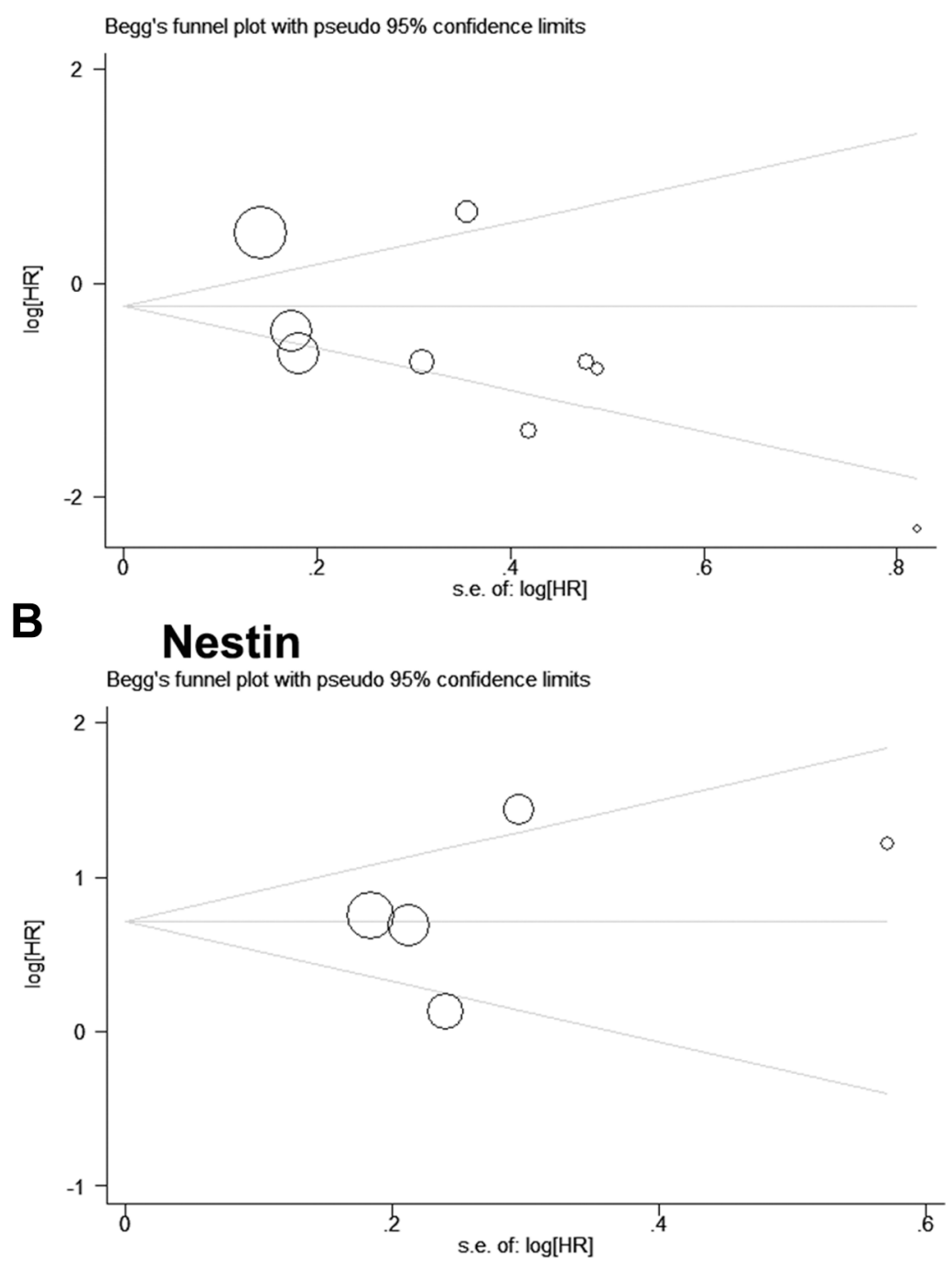

Figure 4: Begg's funnel plot for publication bias analysis. 


\section{MATERIALS AND METHODS}

\section{Publication search}

A systematic search was performed in four English databases (PubMed, EMBASE, OVID, and Web of science) for published articles on the associations of SOX2 and Nestin with clinical features and/or overall survival (OS) in NSCLC up to November 10, 2015. The following keywords were used: "lung OR pulmonary", "cancer OR tumor OR carcinoma", and "Nestin OR Sex determining region Y box-2 OR SRY box-2 OR SOX2". Two independent investigators screened the retrieved documents by reviewing the article titles, abstracts, or full texts according to the inclusion and exclusion criteria. The review articles and the references of selected articles were also screened to identify additional eligible studies.

\section{Inclusion and exclusion criteria}

Inclusion criteria: (1) the histologic type of the tumors was NSCLC and if one study containing multiple types of lung cancer, only the data related to NSCLC was included; (2) evaluating the associations of SOX2 and Nestin DNA amplification and/or protein expression with clinicopathological features and OS; (3) peer reviewed papers that have been published as full texts; (4) the language was limited as English; (5) if mutiple studies contained overlap or duplicated data, only the study with larger sample size was included. Exclusion criteria: (1) the frequency of patients with positive/negative/high/low DNA amplification and protein expression was not specific to clinicopathological features; (2) study with insufficient data; (3) abstracts, letters, or review articles.

\section{Data extraction}

Two independent investigators collected related data carefully and the following characteristics were extracted from included studies: first author name, year of publication, country, ethnicity, patient number, gender, age, protein expression/amplification, method, cut-off value, smoking status, histologic type, differentiation, lymph node metastasis, stage, and OS.

\section{Statistical analysis}

All the statistical analyses were carried out with the software Stata 12.0 (StataCorp, College Station, TX, USA). The crude odds ratios (ORs) with $95 \%$ confidence intervals (95\% CIs) were calculated to estimate the associations of DNA amplification and protein expression of SOX2 and Nestin with clinicopathological features of NSCLC. The crude hazard ratios (HRs) with $95 \%$ CIs were used to assess their clinical significance in predicting prognosis of NSCLC. The statistical significant level was determined by $Z$-test with $P$ value less than 0.05 . If the prognosis was only presented by a Kaplan-Meier plot curve, $\mathrm{HR}$ and its $95 \% \mathrm{CI}$ were calculated according to previous reports $[59,60]$. Briefly, the KM plot curves were read by Engauge Digitizer version 2.11 and HR was estimated by the calculation spreadsheet. The spreadsheet could be freely downloaded from http://www.trialsjournal. com/content/supplementary/1745-6215-8-16-s1.xls. Inconsistency was solved by discussion. The heterogeneity among studies was explored using the chi-square based on $\mathrm{Q}$ statistic test. If $\mathrm{P}>0.1$ or $I^{2}<50 \%$, fixed effects model was used to calculate the pooled OR/HR. Otherwise, random-effects model was used [61]. Sensitivity analysis was also conducted to evaluate stabilities of pooling results by omitting studies that brought heterogeneity or publication bias. Potential publication bias was checked by Begg's funnel plots and Egger's test [62, 63].

\section{CONFLICTS OF INTEREST}

The authors declare no conflicts of interest.

\section{FUNDING}

This study was supported by the grants from National Natural Science Foundation of China (No.81301868) and Higher Educational Science and Technology Program of Shandong Province (No.J15LK04).

\section{Authors' contributions}

Designed the study: Q. L., F. L., and X. M. Searched databases and collected full-text papers: Q. L. and F. L. Extracted and analyzed the data: Y. Z. and L. F. Statistical analyses: Q. L., C. W., X. C., and S. G. Wrote the main manuscript text: Q. L. and X. M. All authors reviewed the manuscript.

\section{REFERENCES}

1. Torre LA, Siegel RL, Jemal A. Lung Cancer Statistics. Adv Exp Med Biol. 2016; 893:1-19.

2. Travis WD. Pathology of lung cancer. Clin Chest Med. 2011; 32:669-692.

3. Fukuoka M, Wu YL, Thongprasert S, Sunpaweravong P, Leong SS, Sriuranpong V, Chao TY, Nakagawa K, Chu DT, Saijo N, Duffield EL, Rukazenkov Y, Speake G, et al. Biomarker analyses and final overall survival results from a phase III, randomized, open-label, first-line study of gefitinib versus carboplatin/paclitaxel in clinically selected patients with advanced non-small-cell lung cancer in Asia (IPASS). J Clin Oncol. 2011; 29:2866-2874.

4. Rosell R, Carcereny E, Gervais R, Vergnenegre A, Massuti B, Felip E, Palmero R, Garcia-Gomez R, Pallares C, Sanchez JM, Porta R, Cobo M, Garrido P, et al. Erlotinib versus standard chemotherapy as first-line treatment for European patients with advanced EGFR mutation-positive non-small-cell lung cancer 
(EURTAC): a multicentre, open-label, randomised phase 3 trial. Lancet Oncol. 2012; 13:239-246.

5. Kwak EL, Bang YJ, Camidge DR, Shaw AT, Solomon B, Maki RG, Ou SH, Dezube BJ, Janne PA, Costa DB, VarellaGarcia M, Kim WH, Lynch TJ, et al. Anaplastic lymphoma kinase inhibition in non-small-cell lung cancer. N Engl J Med. 2010; 363:1693-1703.

6. Bass AJ, Watanabe $\mathrm{H}$, Mermel $\mathrm{CH}, \mathrm{Yu} \mathrm{S}$, Perner S, Verhaak RG, Kim SY, Wardwell L, Tamayo P, Gat-Viks I, Ramos AH, Woo MS, Weir BA, et al. SOX2 is an amplified lineage-survival oncogene in lung and esophageal squamous cell carcinomas. Nat Genet. 2009; 41:1238-1242.

7. Boyer LA, Lee TI, Cole MF, Johnstone SE, Levine SS, Zucker JP, Guenther MG, Kumar RM, Murray HL, Jenner RG, Gifford DK, Melton DA, Jaenisch R, et al. Core transcriptional regulatory circuitry in human embryonic stem cells. Cell. 2005; 122:947-956.

8. Adameyko I, Lallemend F, Furlan A, Zinin N, Aranda S, Kitambi SS, Blanchart A, Favaro R, Nicolis S, Lubke M, Muller T, Birchmeier C, Suter U, et al. Sox2 and Mitf cross-regulatory interactions consolidate progenitor and melanocyte lineages in the cranial neural crest. Development. 2012; 139:397-410.

9. Hussenet $\mathrm{T}$, du Manoir S. SOX2 in squamous cell carcinoma: amplifying a pleiotropic oncogene along carcinogenesis. Cell Cycle. 2010; 9:1480-1486.

10. Maier S, Wilbertz T, Braun M, Scheble V, Reischl M, Mikut R, Menon R, Nikolov P, Petersen K, Beschorner C, Moch H, Kakies C, Protzel C, et al. SOX2 amplification is a common event in squamous cell carcinomas of different organ sites. Hum Pathol. 2011; 42:1078-1088.

11. Freier K, Knoepfle K, Flechtenmacher C, Pungs S, Devens F, Toedt G, Hofele C, Joos S, Lichter P, Radlwimmer B. Recurrent copy number gain of transcription factor SOX2 and corresponding high protein expression in oral squamous cell carcinoma. Genes Chromosomes Cancer. 2010; 49:9-16.

12. Weina K, Utikal J. SOX2 and cancer: current research and its implications in the clinic. Clin Transl Med. 2014; 3:19.

13. Sholl LM, Barletta JA, Yeap BY, Chirieac LR, Hornick JL. Sox2 Protein Expression is an Independent Poor Prognostic Indicator in Stage I Lung Adenocarcinoma. Am J Surg Pathol. 2010; 34:1193-1198.

14. Brcic L, Sherer CK, Shuai Y, Hornick JL, Chirieac LR, Dacic S. Morphologic and Clinicopathologic Features of Lung Squamous Cell Carcinomas Expressing Sox2. Am J Clin Pathol. 2012; 138:712-718.

15. Chou YT, Lee CC, Hsiao SH, Lin SE, Lin SC, Chung CH, Chung $\mathrm{CH}$, Kao YR, Wang YH, Chen CT, Wei YH, Wu CW. The Emerging Role of SOX2 in Cell Proliferation and Survival and Its Crosstalk with Oncogenic Signaling in Lung Cancer. Stem Cells. 2013; 31:2607-2619.

16. Wilbertz T, Wagner P, Petersen K, Stiedl AC, Scheble VJ, Maier S, Reischl M, Mikut R, Altorki NK, Moch H, Fend F, Staebler A, Bass AJ, et al. SOX2 gene amplification and protein overexpression are associated with better outcome in squamous cell lung cancer. Mod Pathol. 2011; 24:944-953.

17. Chen Y, Huang Y, Huang Y, Chen J, Wang S, Zhou J. The prognostic value of SOX2 expression in non-small cell lung cancer: a meta-analysis. PLoS One. 2013; 8:e71140.

18. Park D, Xiang AP, Mao FF, Zhang L, Di CG, Liu XM, Shao Y, Ma BF, Lee JH, Ha KS, Walton N, Lahn BT. Nestin is required for the proper self-renewal of neural stem cells. Stem cells. 2010; 28:2162-2171.

19. Li L, Mignone J, Yang M, Matic M, Penman S, Enikolopov G, Hoffman RM. Nestin expression in hair follicle sheath progenitor cells. Proc Natl Acad Sci U S A. 2003; 100:9958-9961.

20. Huang YL, Wu CM, Shi GY, Wu GC, Lee H, Jiang MJ, $\mathrm{Wu} \mathrm{HL}$, Yang HY. Nestin serves as a prosurvival determinant that is linked to the cytoprotective effect of epidermal growth factor in rat vascular smooth muscle cells. J Biochem. 2009; 146:307-315.

21. Chen Z, Wang T, Luo H, Lai Y, Yang X, Li F, Lei Y, Su C, Zhang X, Lahn BT, Xiang AP. Expression of nestin in lymph node metastasis and lymphangiogenesis in non-small cell lung cancer patients. Hum Pathol. 2010; 41:737-744.

22. Wu B, Sun C, Feng F, Ge M, Xia L. Do relevant markers of cancer stem cells CD133 and Nestin indicate a poor prognosis in glioma patients? A systematic review and meta-analysis. J Exp Clin Cancer Res. 2015; 34:44.

23. Shan YS, Chen YL, Lai MD, Hsu HP. Nestin predicts a favorable prognosis in early ampullary adenocarcinoma and functions as a promoter of metastasis in advanced cancer. Oncol Rep. 2015; 33:40-48.

24. Kurata K, Onoda N, Noda S, Kashiwagi S, Asano Y, Kawajiri H, Takashima T, Tanaka S, Ohsawa M, Hirakawa K. Nestin expression as an independent indicator of poor prognosis for patients with anaplastic thyroid cancer. Oncol Lett. 2015; 10:850-856.

25. Tabata K, Matsumoto K, Minami S, Ishii D, Nishi M, Fujita T, Saegusa M, Sato Y, Iwamura M. Nestin is an independent predictor of cancer-specific survival after radical cystectomy in patients with urothelial carcinoma of the bladder. PLoS One. 2014; 9:e91548.

26. Wu Y, Du X, Xue C, Li D, Zheng Q, Li X, Chen H. Quantification of serum SOX2 DNA with FQ-PCR potentially provides a diagnostic biomarker for lung cancer. Med Oncol. 2013; 30.

27. Shinmura K, Kato H, Matsuura S, Inoue Y, Igarashi H, Nagura K, Nakamura S, Maruyama K, Tajima M, Funai K, Ogawa H, Tanahashi M, Niwa $\mathrm{H}$, et al. novel somatic FGFR3 mutation in primary lung cancer. Oncol Rep. 2014; 31:1219-1224.

28. Rudin CM, Durinck S, Stawiski EW, Poirier JT, Modrusan Z, Shames DS, Bergbower EA, Guan Y, Shin J, Guillory J, Rivers CS, Foo CK, Bhatt D, Stinson J, et al. Comprehensive genomic analysis identifies SOX2 as a frequently amplified gene in small-cell lung cancer. Nat Genet. 2012; 44:1111. 
29. Maier S, Wilbertz T, Braun M, Scheble V, Reischl M, Mikut R, Menon R, Nikolov P, Petersen K, Beschorner C, Moch H, Kakies C, Protzel C, et al. SOX2 amplification is a common event in squamous cell carcinomas of different organ sites. Hum Pathol. 2011; 42:1078-1088.

30. Hussenet T, du Manoir S. SOX2 in squamous cell carcinoma Amplifying a pleiotropic oncogene along carcinogenesis. Cell Cycle. 2010; 9:1480-1486.

31. Xu C, Xie D, Yu SC, Yang XJ, He LR, Yang J, Ping YF, Wang B, Yang L, Xu SL, Cui W, Wang QL, Fu WJ, et al. betacatenin/POU5F1/SOX2 transcription factor complex mediates IGF-I receptor signaling and predicts poor prognosis in lung adenocarcinoma. Cancer Res. 2013; 73:3181-3189.

32. Tatsumori $\mathrm{T}$, Tsuta $\mathrm{K}$, Masai $\mathrm{K}$, Kinno $\mathrm{T}$, Taniyama $\mathrm{T}$, Yoshida A, Suzuki K, Tsuda H. p40 is the Best Marker for Diagnosing Pulmonary Squamous Cell Carcinoma: Comparison With p63, Cytokeratin 5/6, Desmocollin-3, and Sox2. Appl Immunohistochem \& Mol Morphol. 2014; 22:377-382.

33. Cortes-Dericks L, Galetta D, Spaggiari L, Schmid RA, Karoubi G. High expression of octamer-binding transcription factor 4A, prominin-1 and aldehyde dehydrogenase strongly indicates involvement in the initiation of lung adenocarcinoma resulting in shorter disease-free intervals. Eur J Cardiothorac Surg. 2012; 41:e173-e181.

34. Han SS, Kim WJ, Hong Y, Hong SH, Lee SJ, Ryu DR, Lee W, Cho YH, Lee S, Ryu YJ, Won JY, Rhee H, Park JH, et al. RNA sequencing identifies novel markers of non-small cell lung cancer. Lung Cancer. 2014; 84:229-235.

35. Ahmed MB, Nabih ES, Louka ML, Abdel Motaleb FI, El Sayed MA, Elwakiel HM. Evaluation of nestin in lung adenocarcinoma: Relation to VEGF and Bcl-2. Biomarkers. 2014; 19:29-33.

36. Chiou GY, Cherng JY, Hsu HS, Wang ML, Tsai CM, Lu KH, Chien Y, Hung SC, Chen YW, Wong CI, Tseng LM, Huang PI, Yu CC, et al. Cationic polyurethanes-short branch PEI-mediated delivery of Mir145 inhibited epithelialmesenchymal transdifferentiation and cancer stem-like properties and in lung adenocarcinoma. J Control Release. 2012; 159:240-250.

37. Yuan P, Kadara H, Behrens C, Tang X, Woods D, Solis LM, Huang J, Spinola M, Dong W, Yin G, Fujimoto J, Kim E, Xie Y, et al. Sex determining region Y-Box 2 (SOX2) is a potential cell-lineage gene highly expressed in the pathogenesis of squamous cell carcinomas of the lung. PLoS One. 2010; 5:e9112.

38. Lu Y, Futtner C, Rock JR, Xu X, Whitworth W, Hogan BL, Onaitis MW. Evidence that SOX2 overexpression is oncogenic in the lung. PLoS One. 2010; 5:e11022.

39. Sholl LM, Long KB, Hornick JL. Sox 2 Expression in Pulmonary Non-small Cell and Neuroendocrine Carcinomas. Appl Immunohistochem \& Mol Morphol. 2010; 18:55-61.

40. Cai YR, Zhang HQ, Qu Y, Mu J, Zhao D, Zhou LJ, Yan H, Ye JW, Liu Y. Expression of MET and SOX2 genes in nonsmall cell lung carcinoma with EGFR mutation. Oncol Rep. 2011; 26:877-885.
41. Cai YR, Zhang HQ, Zhang ZD, Mu J, Li ZH. Detection of MET and SOX2 amplification by quantitative real-time PCR in non-small cell lung carcinoma. Oncol Lett. 2011; $2: 257-264$.

42. Tsuta K, Tanabe Y, Yoshida A, Takahashi F, Maeshima AM, Asamura H, Tsuda H. Utility of 10 Immunohistochemical Markers Including Novel Markers (Desmocollin-3, Glypican 3, S100A2, S100A7, and Sox-2) for Differential Diagnosis of Squamous Cell Carcinoma from Adenocarcinoma of the Lung. J Thorac Oncol. 2011; 6:1190-1199.

43. Sasaki H, Yokota K, Hikosaka Y, Moriyama S, Yano M, Fujii Y. Increased Sox2 copy number in lung squamous cell carcinomas. Exp Ther Med. 2012; 3:44-48.

44. Li X, Wang J, Xu Z, Ahmad A, Li E, Wang Y, Qin S, Wang Q. Expression of Sox 2 and Oct4 and Their Clinical Significance in Human Non-Small-Cell Lung Cancer. Int J Mol Sci. 2012; 13:7663-7675.

45. Chen S, Xu Y, Chen Y, Li X, Mou W, Wang L, Liu Y, Reisfeld RA, Xiang R, Lv D, Li N. SOX2 Gene Regulates the Transcriptional Network of Oncogenes and Affects Tumorigenesis of Human Lung Cancer Cells. Plos One. 2012; 7.

46. Velcheti V, Schalper K, Yao X, Cheng H, Kocoglu M, Dhodapkar K, Deng Y, Gettinger S, Rimm DL. High SOX2 Levels Predict Better Outcome in Non-Small Cell Lung Carcinomas. Plos One. 2013; 8.

47. Inoue Y, Matsuura S, Kurabe N, Kahyo T, Mori H, Kawase A, Karayama M, Inui N, Funai K, Shinmura K, Suda T, Sugimura H. Clinicopathological and Survival Analysis of Japanese Patients with Resected Non-Small-Cell Lung Cancer Harboring NKX2-1, SETDB1, MET, HER2, SOX2, FGFR1, or PIK3CA Gene Amplification. J Thorac Oncol. 2015; 10:1590-1600.

48. Toschi L, Finocchiaro G, Nguyen TT, Skokan MC, Giordano L, Gianoncelli L, Perrino M, Siracusano L, Di Tommaso L, Infante M, Alloisio M, Roncalli M, Scorsetti M, et al. Increased SOX2 Gene Copy Number Is Associated with FGFR1 and PIK3CA Gene Gain in NonSmall Cell Lung Cancer and Predicts Improved Survival in Early Stage Disease. Plos One. 2014; 9.

49. Yoon HI, Park KH, Lee EJ, Keum KC, Lee CG, Kim CH, Kim YB. Overexpression of SOX-2 is Associated with Better Overall Survival in Squamous Cell Lung Cancer Patients Treated with Adjuvant Radiotherapy. Cancer Res Treat. 2016; 48:473-82. doi: 10.4143/crt.2015.116.

50. Iijima Y, Seike M, Noro R, Ibi T, Takeuchi S, Mikami I, Koizumi K, Usuda J, Gemma A. Prognostic significance of PIK3CA and SOX2 in Asian patients with lung squamous cell carcinoma. Int J Oncol. 2015; 46:505-512.

51. Zheng S, Pan Y, Wang R, Li Y, Cheng C, Shen X, Li B, Zheng D, Sun Y, Chen H. SOX2 expression is associated with FGFR fusion genes and predicts favorable outcome in lung squamous cell carcinomas. Onco Targets Ther. 2015; 8.

52. Janikova M, Skarda J, Dziechciarkova M, Radova L, Chmelova J, Krejci V, Sedlakova E, Zapletalova J, Langova K, 
Klein J, Grygarkova I, Kolek V. IDENTIFICATION OF CD133(+)/NESTIN+ PUTATIVE CANCER STEM CELLS IN NON-SMALL CELL LUNG CANCER. Biomed Pap Olomouc. 2010; 154:321-326.

53. Ryuge S, Sato Y, Wang GQ, Matsumoto T, Jiang SX, Katono K, Inoue H, Satoh Y, Masuda N. Prognostic Significance of Nestin Expression in Resected Non-small Cell Lung Cancer. Chest. 2011; 139:862-869.

54. Skarda J, Kolar Z, Janikova M, Radova L, Kolek V, Fridman E, Kopolovic J. Analysis of the prognostic impact of nestin expression in non-small cell lung cancer. B Biomed Pap Olomouc. 2012; 156:135-142.

55. Chen Z, Wang J, Cai L, Zhong B, Luo H, Hao Y, Yu W, Wang B, Su C, Lei Y, Bella AE, Xiang AP, Wang T. Role of the Stem Cell-Associated Intermediate Filament Nestin in Malignant Proliferation of Non-Small Cell Lung Cancer. Plos One. 2014; 9.

56. Sterlacci W, Savic S, Fiegl M, Obermann E, Tzankov A. Putative Stem Cell Markers in Non-Small-Cell Lung Cancer A Clinicopathologic Characterization. J Thorac Oncol. 2014; 9:41-49.

57. Shao W, Chen H, He J. The role of SOX-2 on the survival of patients with non-small cell lung cancer. J Thorac Dis. 2015; 7:1113-1118.
58. Zhong B, Wang T, Zou J, Zheng F, Huang R, Zheng X, Yang W, Chen Z. Association of the intermediate filament nestin with cancer stage: a meta-analysis based on 223 positive/high nestin cases and 460 negative/low case-free controls. Oncotarget. 2015; 6:22970-22977. doi: 10.18632/ oncotarget.4042.

59. Wang Y, Zeng T. Response to: Practical methods for incorporating summary time-to-event data into metaanalysis. Trials. 2013; 14:391.

60. Tierney JF, Stewart LA, Ghersi D, Burdett S, Sydes MR. Practical methods for incorporating summary time-to-event data into meta-analysis. Trials. 2007; 8:16.

61. R. D, N. L. Meta-analysis in clinical trials. Control Clin Trials. 1986; 7:177-188.

62. Begg CB, Mazumdar M. Operating characteristics of a rank correlation test for publication bias. Biometrics. 1994; 50:1088-1101.

63. Egger M, Davey Smith G, Schneider M, Minder C. Bias in meta-analysis detected by a simple, graphical test. BMJ. 1997; 315:629-634. 